\title{
STRATEGI MANAJEMEN KONFLIK DALAM INTERAKSI SIBLING
}

\author{
Irwan Nuryana Kurniawan \\ Universitas isian indonesia
}

\section{[NTISAR|}

Tulisan ini bermaksud menelaah apa dan bagaimana interaksi antarsibling terjadi, mengapa konfik antara sibling teriadi, senta strategi yang digunakan para orangtua dalam menangani konflik yang terjadi di antara anakanaknya. Menurut penulis, para orangtua hendaknya memperhatikan faktor-faktor berikut ini, yaitu (a) karakteristik anak, (b) jenis kelamin anak, (c) perbedaan usia antar sibling, (d) jenis konflik.

Kata kuncl: strategi manajemen konflik, orangtua, interaksi sibling

Irwan Nuryana Kurn/awan adalah dosen Fakultas Psikologi Universitas Islam indonesia. Minat utamanya adalah psikologi perkembangan (torutama kajian anak dan remaja), psikologi pendidikan, dan psikologi sosial.

PSIKOLOGIKA Nomor 11 Tahun VI 2001

\section{PENDAHULUAN}

alah satu tugas tersulit yang dihadapi - para orangtua adalah memutuskan bagaimana merespon secara cepat dan tepat ketika terjadi konflik di antara anak-anak mereka. Mengapa demikian? Cepat lambatnya dan tepat tidaknya strategi manajemen konllik yang digunakan orangtua tidak hanya berdampak pada teratasinya konflik yang muncul, tapi juga bagi perkembangan kehidupan anak-anak ini di masa mendatang.

Dalam buku Emotional Intelligence; Goleman (1995) mencatat:

"There are hundreds of studies showing that how parents treat their children-m whater with harsh discipline or empathetic understanding. with indifference or warmth, and so on-has deep and lasting consequence for the child's emotional life. Oniy racently, though, have there been data showing that having emotionally in telligent parient is itself of enormous to the 
child. The ways a couple handles the feeling betweon them $\rightarrow$ in addition their dired dealings with the child- impart powerful lossons to their children, who are astute learners, attuned to the subte emotional exchanges in the family."

Grusec dan Goodnow (dalam Perozynski dan Kramer, 1999) mendapati bahwa pemakaian strategi reasoning berkorelasi positif dengan kepribadian anak yang adaptif. Dalam strategi reasoning, orangtua mengajak anak berdiskusi mengapa perilaku mereka dikatakan tidak pantas. Sebagai contoh, dengan melihat kembali konsekuensi suatu perilaku, orangtua menggambarkan bagaimana harapan-harapan normatif telah dilanggar oleh mereka.

Alasan inilah yang mendorong penulis untuk mengangkat topik strategi manajemen konflik dakam tulisan kaki ini. Bagian pertama tulisan ini mencoba menjelaskan apa dan bagaimana interaksi sibling, serta mengapa terjadi konflik di antara sibling. Bagian kedua, apa yang biasanya dilakukan orangtua ketika menghadapi konflik antara sibling serta faktor-faktor apa yang perlu diperhatikan para orangtua dalam menangani konflik yang terjadi di antara anak mereka. Bagian terakhir, saran-saran praktis yang dapat dilakukan orangtua dalam mengelola konflik yang terjadi.

\section{INTERAKSI SIBLING:}

\section{APA, BAGAIMANA, DAN MENGAPA?}

Interaksi sibling atau interaksi antar saudara kandung, disebut beberapa buku sebagai sibling relationship, merupakan fenomena alamiah yang tumbuh dan berkembang dalam kehidupan sebuah keluarga. Fenomena in biasanya muncul dàlam sebuah keluarga yang memiliki dua anak atau lebih. Interaksi sibling, menurut
Jolley dan Mitchel (1996) merupakan konsekuensi alamiah dari adanya perubahan struktur keluarga. Setiap kali ada penambahan anggota keluarga baru, maka akan terjadi peningkatan jumlah interaksi di antara anggota keluarga.

Sening dikatakan sibling menyayangi satu sama lain. Sibling membenci satu sama lain. Pada setiap interaksi sibling. dalam berbagai variasi, kedua pernyataan tersebut adalah benar. Ambivalensi perasaan positif dan negatif merupakan ciri khas interaksi sibling sepanjang kehidupan.

Sebenarnya, menurut Brendt (1992), sejak dini dapat dilihat ambivalensi ini pada reaksi awal anak yang lebih tua terhadap kelahiran saudara mudanya, baik saudara laki-laki maupun saudara perempuan. Anakanak yang lebih tua seringkali bereaksi secara positif terhadap saudaranya yang baru lahir. Mereka mencoba memberi makan dan rasa nyaman terhadap adiknya. Mereka juga memperhatikan bagaimana orangtuanya merawat adiknya dan mereka mencoba meniru apa yang dilakukan orangtuanya terhadap adiknya tersebut.

Hal ini membuat anak yang lebih tua menjadi attachmem object yang sama baiknya seperti orangtuanya. Tahun 1983 Robert Stewart membuktikan fenomena tersebut. Stewart (dalam Shaffer, 1994), dengan menggunakan Strange-Situations Test, menemukan bayi yang berusia antara 10 sampai dengan 20 bulan seringkali mendekat kepada kakak laki-laki atau kakak perempuannya yang lebih tua (berusia sekitar empat tahun), terutama ketika muncul orang yang tidak dikenalnya. Mereka, anak-anak yang berusia empat tahun ini, bertindak sebagai sumber kenyamanan, caregiving bagi adik laki-laki atau perempuannya.

Menurut Santrock (2001), interaksi antar sibling seringkali menunjukkan momenmomen yang positif melalui dukungan sosial 
dan komunikasi sosial. Menolong adiknya yang lebih muda mengatasi situasi tidak menentu saat orangtua mereka tidak ada. Lebih dari itu, adik kerapkali menjadikan kakaknya sebagai a secure base untuk melakukan eksplorasi kompetensi yang dimiliki dan melakukan penyesuaian diri ketika teman sebayanya mengabaikan mereka. Anak yang lebih tua, menurut Samuels, Stewart dan Marvin (dalam Shatter, 1994) menjadi sumber dukungan emosional yang penting.

Brody, Stoneman \& MacKinnon (dalam Shatter, 1994) menemukan bahwa anak yang lebih tua, berusia 8 sampai dengan 10 tahun, mendominasi dalam interaksi sibling dan banyak memainkan peran as a teacher or a managerdibandingkan saudara yang lebih muda, berusia 4,5-7 tahun. Ketika mereka bermain dengan teman sebaya, sama-sama berusia 8-10 tahun, mereka berperan sebagai equal status playmate. Ketika ketiga kelompok ini bermain bersama-sama, anak yang lebih tua mengasumsikan dirinya lebin bertanggung jawab, daripada teman sebayanya, untuk mengarankan saudaranya yang lebih muda. Anak yang lebin tua tampak menunjukkan usahausaha aktit memerintahkan saudaranya yang lebih muda. Riset yang dilakukan Noman dan Jackson (dalam Shaffer, 1994) juga menunjukkan ketika saudaranya yang lebin muda mengalami kesulitan dalam membaca, mereka meminta saudaranya yang lebih tua berperan seperti orang yang di sekolah mengajari huruf ABC.

Di sisi yang lain, terkadang anak yang lebih tua bereaksi secara negatit terhadap kehadiran saudara laki-laki atau saudara perempuannya yang baru lahir. Reaksi negatif ini tampaknya bersumber dari kecemburuan. Seringkali masalah perilaku tampak ketika ibu sedang memperlihatkan afeksi terhadap adiknya.
Stewart (dalam Brendt, 1992) mencatat intensitas reaksi negatif anak yang lebih tua, laki-laki maupun perempuan, terhadap adiknya, bervariasi sesuai dengan usia adik. Selama bulan pertama setelah bayi lanir. saudara laki-laki dan perempuan yang lebih tua seringkali memperlihatkan frekuensi menangis dan merengek yang meningkat. Jika anak yang lebih tua ini telah diberi toilet training sebelum bayi lahir, mereka mungkin akan mengalami toilet accident.

Perilaku seperti ini dapat dilinat sebagai proses regresi. Anak kembali ke tase perkembangan sebelumnya yang belum matang. Anak mencoba kembafi menarik perhatian ibunya. Mengapa demikian? Karena kebanyakan para ibu menunjukkan penurunan trekuensis interaksi dengan anak pertamanya ketika mereka memiliki bayl yang baru. Anak-anak yang lebih tua merasa kecewa dan membutuhkan kehangatan. Mereka ingin ibu berinteraksi dengan mereka seperti saat adiknya belum lahir.

Penyesuaian anak pra sekolah setelah kelahiran adiknya, menurut Dunn (dalam Brendt, 1992), dipengaruni oleh perilaku orangtua mereka. Masalah perilaku anak yang lebin tua jarang terjadi jika orangtua tetap memberikan perhatian kepada anak yang lebin tua kelika bayi baru lahir. lbu dapat melibatkan mereka daiam interaksi ibu-adik baru, mendorong sibling yang lebih tua untuk menolong adiknya. Jika harus memberikan seluruh perhatian kepada bayi yang baru lahir, ibu bisa mengurangi konflik dengan cara memberikan kesibukan terhadap sibling yang lebih tua.

Sebagai contoh, ketika ibu sedang mempersiapkan makanan bayi, sebelumnya ibu bisa memberikan anak yang lebih tua minuman, snack, buku, krayon dan kertas. Para ayan, menuru Stewart (dalam Shaffer. 1994) juga dapat memainkan peran penting dengan meningkatkan trekuensi waktu interaksi mereka untuk anak yang lebih tua., 
Sesungguhnya, saat para ibu memperhatikan kebutuhan stimulasi dan perhatian anak-anak yang lebih tua, ini tidak hanya mengurangi kemungkinan terjadinya masalah perilaku pada mereka, tapi juga membantu mereka membentuk hubungan yang lebih baik dengan adik barunya.

Ambivalensi perasaan positif-negatif dalam interaksi antar sibling terus berlanjut, sejalan dengan bertambahnya usia mereka. Perbedaan kematangan antara sibling yang lebih tua dan yang lebih muda juga mempengaruhi interaksi mereka. Anak yang lebih tua memiliki power dan kompetensi lebih besar daripada saudara mudanya.

Abramovitch dkk (dalam Brendt, 1992) dalam penelitian longitudinalnya menemukan bahwa anak-anak yang lebih tua lebih prososial daripada saudara mudanya. Perbedaan ini merefleksikan besarnya kompetensi anak-anak yang lebih tua. Mereka dapat menolong saudara mudanya karena mereka lebih kuat dan tahu lebih banyak daripada saudara mudanya. Mereka juga selaiu memulai perkelahian dan lebih agresif daripada saudara mudanya. Mereka menggunakan power mereka yang lebih besar sama baiknya, untuk menyakiti maupun menolong saudara mereka yang lebih muda.

Abramovitch dkk (dalam Brendt, 1992) juga menemukan bahwa anak-anak yang lebih muda memperlihatkan usaha meniru yang lebih kuat daripada anak-anak yang lebih tua. Anak-anak yang lebih muda sering memandang kakaknya sebagai seorang ahli-mengajari mereka bagaimana melakukan sesuatu. Mereka belajar tentang dunia dan apa-apa yang ada di dalamnya dari kakaknya. Kakak juga mendapatkan keuntungan dari interaksi dengan adiknya, yaitu meningkatnya pemahaman mereka tentang apa yang mereka ajarkan.

Interaksi antar sibling berubah ketika mereka beranjak remaja dan dewasa. Buhrmester dan Fuhrmann (dalam Brendt.
1992) menemukan bahwa dengan bertambahnya usia, para remaja melaporkan berkurangnya dominasi dan perlaku prososial mereka Dengan kata lain, baik aspek positif dan negatif power dari anak yang lebih tua menjadi tidak menonjol ketika mereka beranjak remaja. Hal yang sama juga ditunjukkan remaja dalam hal persahabatan di antara mereka.

Apa yang dikemukakan di atas menunjukkan bahwa interaksi antar sibling akan berkembang menjadi hubungan yang positif atau menjadi konflik antara sibling. tergantung pada perlakuan yang diberikan oleh orangtua. Anak yang lebih tua memperlihatkan konflik lebih sedikit dengan adiknya jika orangtua mereka memberikan perhatian yang relatif sama terhadap mereka.

Sebaliknya, jika orangtua tidak memperlakukan semua anak secara seimbang, favoritisme orangtua akan mempengaruhi penyesuaian psikologis anak-anak. $\mathrm{ke}$. mungkinan terjadinya konflik antar sibling menjadi lebih besar, bak berupa konflik fisik seperti perkelahian, maupun konflik verbal, seperti pertengkaran.

\section{Strategi Manajemen Konflik \\ Dalam Interaksi Sibling: Apa, Bagaimana dan Mengapa?}

Strategi manajemen konflik dalam interaksi sibling adalah cara-cara yang digunakan oleh para orangtua sebagai respon atas konflik yang terjadi di antara anak-anak mereka. Yang perlu diperhatikan di sini, meskipun antara gaya-gaya pendisiplinan orangtua dan strategi manajemen konflik dalam interaksi sibling bisa digambarkan sebagai sesuatu yang paralel, proses keduanya tldaklah sama. Gaya pendisiplinan orangtua dikaji dalam konteks hubungan orangtuaanak, sementara yang terakhir dalam konteks orangtua-sibling. 
Ada perbedaan penting dalam cara orangtua menampilkan strategi reasoning pada kedua konteks. Sebagai contoh, ketika tujuan reasoning dalam konteks hubungan orangtua-anak adalah membuat anak berkomunikasi dengan orangtua tentang perilaku mereka yang menyimpang, dalam konteks sibling tujuan strategi reasoning adalah membuat anak-anak mereka saling berkomunikasi satu sama lain tentang posisi masing-masing dan usaha-usaha mereka untuk memecahkan masalah.

Beberapa studi menunjukkan ada berbagai strategi yang biasa digunakan orangtua dalam menangani konffik sibling. Vuchinich, Emery, dan Cassidy (dalam Perozynski dan Kramer, 1999) mengklasifikasikan strategi manajemen konflik yanig digunakan orangtua meliputi (a) kontinyuasi konflik (terlibat atau memperluas konfllk), (b) otoritas (menggunakan power untuk mengakhiri konflik), (c) mediasi (memberi saran, memberikan informasi), (d) distraksi (mengubah fokus terhadap isu-isu nonkonflik), dan (e) nonin. tervention

Sementara itu, Grusec dan Goodnow (dalam Perozynski dan Kramer. 1999) membagi respon orangtua terhadap konflik dalam interaksi sibling menjadi tiga kategor: reasoning, power assertion, dan love withdrawal. Reasoning melibatkan diskusi dengan anak tentang mengapa perilaku mereka dikatakan tidak tepat. Contohnya, dengan melihat kembali konsekuensi sebuah perilaku, mendeskripsikan bagaimana harapan-harapan normatif telah dilanggar. Power assertion mencakup hukuman fisik, pemaksaan, pencabutan hak-hak istimewa, ancaman-ancaman, atau perintah-perintah. Love withdrawa/meliputi mengekspresikan penolakan, perasaan maku, atau dihina secara langsung.

Perozynski dan Kramer (1999) juga mengidentifikasi ada tiga strategi manajemen konflik. Pertama, strategi child-centered, yaitu perilaku-perilaku responsif orangtua ditujukan membantu anak berkomunikasi salu sama lain tentang posisinya masingmasing. Termasuk dalam strategi ini adalah negosiasi, reasoning, kompromi, dan pemecahan masalah.

Kedua, strategi parental-control, yaitu perilaku-perilaku orangtua yang ditujukan untuk mengeliminasi konflik melalui perilaku-perilaku yang bersifat punitif, arıcaman-ancaman, pecabutan hak-hak istimewa, atau tindakan-tindakan kontrol. Ketiga, strategi passive nonintervention yang ditandai oleh tidak adanya intervensi orangtua terhadap kontlik sibling.

Perozynski dan Kramer (1999) mencatat dari penelitian Dunn dan Munn tahun 1986. Felson dan Russo tahun 1988. Perlman dan Ross tahun 1997 , serta Ross, Filyer, Lolls, Perlman, \& Martin tahun 1994, bahwa efektivitas strategi managemen konflik yang digunakan para orangtua bervariasi secara spesifik. Artinya suatu strategi yang efektif memecahkan konflik antara saudara pada satu situasi, belum tentu efektif digunakan untuk jenis konflik yang sama pada situasi yang berbeda.

Ada beberapa faktor, terutama faktorfaktor perkembangan, yang perlu diperhatikan oleh para orangtua agar efektivitas strategi manajemen konflik dapat tercapai. Ketika mendapati konflik terjadi antara anakanak kita yang beranjak remaja, misalnya, maka harus diperhatikan karakteristik khusus atau dalam konsepnya Havighurst (dalam Hoftman dkk., 1994) dikenal sebagai developmental tasks apa yang diemban oleh remaja.

Pernaharnantentang Ligas perkembangan remaja ini akan sangat membantu dalam menangani konflik sibling pada remaja. Strategi yang efektif pada anak belum tentu efektif dikenakan pada remaja, karena jenis dan kompleksitas tugas perkembangan antara anak dengan remaja adalah berbeda. 
Dalam suatu reviewliteratur, Brody dan Shaffer (daiam Perozynski \& Kramer, 1999) menyimpulkan bahwa orangtua melihat reasoning lebih dekat hubungannya dengan perkembangan moral lanjut pada anak usia 7 tahun dan di atasnya. Lebih lanjut, orang:La meyakini strategi parental control relatif paling tepat pada anak yang lebih muda karena mereka kecil kemungkinannya mendapatkan keuntungan dari pendekatan induktif.

Pertama, faktor perkembangan yang perlu diperhatikan adalah karakateristik anak. Orang:ua mungkin percaya bahwa strategi :ertentu, strategi child-centered misainya, akan lebih efektif mengatasi konflik antar saudara pada anak-anak yang lebih tua karena mereka lebih mudah diajak dalam sebuah diskusi yang komplek, reasoning, perspective taking, dan negosiasi. Sementara itu, strategi passive nonintervention mungkin dipandang paling tepat pada anak yang lebih tua, karena dipersepsi lebih kapabel dalam mengatasi konflik mereka sendiri.

Kedua, jenis kelamin anak. Ada sesuatu yang unik dalam hubungan antara sibling dengan jenis kelamin yang sama. Minnet, Vandefl, dan Santrock (Santrock, 1999) menemukan bahwa perilaku agresif dan dominasi lebih sering terjadi pada hubungan antar sibling dengan jenis kelamin yang sama dibandingkan hubungan antar sibling dengan jenis kelamin yang berbeda. Grusec dan Goodnow (dalam Perozynski dan Kramer, 1999) juga menemukan bahwa orangtua kemungkinan besar menggunakan pendekatan inductive-rieasoningpada wanita dan power assertion pada laki-laki.

Ketiga, usia dan perbedaan usia antar sibting. Felson dan Russo (dalam Perozynski dan Kramer, 1999) menemukan bahwa orangtua kemungkinan akan melakukan intervensi untuk melindungi anak yang lebih muda, serutama konflik yang terjadi antara wanita dengan anak laki-laki yang lebih :La. Perozynski dan Kramer (1999) juga menemukan bahwa ayah relatif lebih sering memakal strategi child-centered pada anak pertama dan ketika jarak usia antara sibling lebih kecil.

Keempat, jenis konflik. Perozynski dan Kramer (1999) menemukan bahwa para ibu meyakini strategi child-centeredlebih efektif daripada strategi parental control dalam mengatasi konflik verbal. Sebaliknya, para ayah merasa justru kedua strategi tersebut sama-sama efektif dalam memecahkan konflik verbal. Sementara para ayah menunjukkan konfidensi yang tinggi dalam memakai strategi parental control dibandingkan strategi child-centered dalam merespon konflik verbal, para ibu justru sama-sama merasa percaya diri untuk menampilkan kedua strategi tersebut.

Ada satu hal menarik yang ditemukan dari berbagai literatur dan hasil penelitian, yaitu perbedaan keyakinan ibu dan ayah tentang efektivitas strategi manajemen konflik. Ternyata, dalam beberapa hal ayah dan ibu tidak jarang memperlihatkan perbedaan persepsi tentang bagaimana seharusnya menangani konfik yang terjadi di antara anak-anak mereka.

Hal ini menjadi menarik karena mungkin saja sebulah strategi itu, misalnya hukuman, efektif menuru: keyakinan ayah, tetapi menurut bu tidak. Perlman dan Ross (dalam Perozynski dan Kramer, 1999) menemukan bahwa bu, dibandingkan ayah, kemungkinan besar melakukan intervensi terhadap konfijk anak-anaknya. Ayah cenderung menggunakan sikap otoriter ketika melakukan intervensl dalam konflik-konflik sibling. sedangkan ibu cenderung memakai pendekatan mediasional.

Adanya perbedaan bellef ini dikaji secara mendalam oleh Perozynski dan Kramer (1999). Perozynski dan Kramer (1999) dalam penelitiannya terhadap 82 
pasang orangtua, yang memiliki dua orang anak, menemukan bahwa saktor kognitit memiliki peran yang sangat penting dan menentukan ketika seseorang memilih suatu strategi managemen konflik. Faktor. kognitif yang dimaksudkan di sini adalah belief para orangtua tentang strategi manajemen konflik yang paling efektif untuk mengatasi konflik yang terjadi pada anak mereka.

Sebagai contoh, Simons, Whitback. Conger dan Chyi-in (dalam Perozynski dan Kramer, 1999) menemukan orangtua yang meyakini bahwa kekerasan dalam teknik pengasuhan itu adaiah tepat, cenderung melaporkan lebih sering melakukan perilaku tersebut daripada orangtua yang memiliki befiet sebaliknya.

Belig, menu rut perilaku Crick dan Dodge (dalam Perozynski dan Kramer, 1999) merupakan representasi mental mengenai realitas, yang terbentuk oleh pengalamanpengalaman masa lalu dan masa kini dan disimpan dalam long-term memory. Skema spesițk, beliet, dan harapan terintegrasi dalam belief system, yang akan mempengaruhi proses interpretasi individu serhadap situasi spesifik. Proses interpretasi terhadap situasi spesifik ini, pada gilirannya, diprediksi akan mempengaruhi perilakunya

lbu kemungkinan besar akan menggunakan strategi child-centered, lanjut Perozynski dan Kramer (1999), jika ibu merasa strategi child centered dianggap efektif dalam menangani kontlik antara sibling (harapan hasil yang positif) dan ibu merasa yakin bisa menampilkan strategi ini dengan baik (harapan self-efficacy yang positit). Begitu juga dengan ayah. Ayah cenderung menggumakan strategi parental controlkarena harapan hasil yang positit dan harapan self efficacyyang positit terhadap strategi ini daiam menangani kontlik.

Jadi, belief di sini mencakup dua tipe. Pertama, belief tentang tipe-tipe strategi manajemen kontlik yang paiing etektit dalam memecahkan konflik sibling (parental outcome expectation). Kedua, belief tentang tipe-tipe strategi manajemen konfiik di mana para orangtua merasa paling konfidens menampilkannya (parental selfefficacy expectation).

Kedua tipe belief ini berinteraksi satu sama iain dalam memprediksi respon apa yang akan ditampilkan orangtua terhadap konflik sibling yang terjadi. Orangtua mungkin meyakini bahwa strategi yang dapat mereka tampilkan (a positive outcome expectation) adalah strategi yang paling etektit (a positive self-efficacy expectation). Alternatit lain, orangtua mungkin meyakini bahwa suatu strategi khusus akan efektif mengatasi konflik (a positive outcome expectation), tapi orangtua tidak melakukannya karęna mereka tidak yakin mampu menampilkan strategi tersebut secara efektit (a negative self-efficacy ex. pectation).

Sebagai contoh, Perozynski dan Kramer (1999) dalam peneltiannya menemukan bahwa pemakaian strategi child-centeredoleh para ibu dapat diprediksikan oleh belie! mereka bahwa strategi parental controf tidak etektits. Jadi, para ibu memakai strategi ini bukan karena keyakinan mereka bahwa sirategi ini secara khusus efektit, tetapi lebih disebabkan oleh strategi altematif dipandang sia-sia.

\section{PENUTUP}

Sebagai penutup, penulis kutipkan saran-saram praktis yang dapat dilakukan dalam menangani konflik sibling. Tip-tips berikut penulis ambil dari artikel Goyer (2000), How to Manage Sibling Conflict. Mereka adalah:

Pertama, biarkan pertikaian itu padam. Setelah pertengkaran atau perkelahian dihentikan, call cease fire. Beri kesempatan beberapa saat anak Anda untuk menenangkan 
diri. Dengarkan cerita dari kedua belah pihak. Dengarkan tanpa memihak salah satu.

Kedua, tegakkan aturan. Ingatkan anak terhadap peraturan-peraturan yang sekarang berlaku di rumah. Akan sangat baik jika aturan-aturan ini terpasang di dinding rumah sehingga memudahkan orangtua memperlihatkan kepada anak aturan-aturan standar mana yang mereka langgar

Ketiga, jika diperlukan, cari pemicu Konfliknya. Setelah menemukan siapa yang bertanggung jawab atas konfik tersebut dan mengacu pada aturan yang ada, penegakan aturan akan sia-sia tanpa memberi konsekuensi yang pantas bagi mereka yang melanggar aturan

Keempat, dorong untuk saling memaafkan. Setelah disiplin ditegakan, damaikan keduanya dan dorong mereka untuk saling meminta maaf. Tunjukkan tentang kelebihan dan kelemahan yang dimiliki setiap anak. Minta mereka untuk saling berpelukan, ingatkan bahwa berjahat tangan terasa akan lebih enak daripada berkonfilk.

Kelima, buatiah misi keluarga. Berkumpulah bersama-sama untuk menulis pernyataan misi keluarga, tanda tangani oleh setiap anggota keluarga, guna mencapai tujuan ke depan. Libatkan setiap anggota keluarga dalam mengembangkan apa yang menjadi fokus keluarga, perilaku-perilaku yang diharapkan dan tujuan-tujuan yang akan dicapai.

Keenam, ajari untuk menyatakan ketidaksetujuan. Daripada saling memukul ketika terjadi konflik, ajari anak-anak ketrampilan berkomunikasi untuk memecahkan konflik yang mereka hadapi. Menyatakan ketidaksetujuan atas perilaku saudaranya tanpa harus menyinggung harga diri atau perasaannya. Jaditah contoh yang baik dalam mengatasi konflik dengan cara-cara yang sehat, tidak saling menyakiti.

Ketujuh, belajar damai dengan bermain peran. Salah satu cara untuk menghentikan potensi atau terulangnya kembali konflik adalah melalui bermain peran. Minta anakanak untuk bertukar peran satu sama lain. Ini merupakan salah satu cara bagi anak untuk memahami perasaan-perasaan dan emosi-emosi sabdaranya. Dari sinidiharapkan mereka memiliki argumen yang kuat dan menunjukkan cara-cara mengatasi konflik secara damai.

Kedelapan, semaikan persatuan keluarga. Dorong setiap anggota keluarga menyatukan kekuatan, bekerja bersamasama ketika menghadapi kasus yang sama dan memberikan dukungan satu sama lain. Setiap pribadi harus didorong untuk melindungi perasaan keluarga, menjaga nama baik keluarga. $]$

\section{DAFT AR PUSTAKA}

Goleman, D. 1995. Emotional Intelligence. New York: Bantam Books.

Goyer, T. 2000. How to Manage Sibling Conflict. Http://www.noahsays.com/ article.asp? aid $=914$.

Hoffman, L., Paris, S., \& Hall, E 1994. Developmental. Psychology Today (6 $6^{\text {m }}$ ed). NeW York McGraw-Hill Companies.

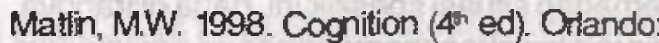
Harcourt Brace College Publishers.

Molley, J.M, \& Mitchell, M.L. 1996. Lfe Span Development: A Topical. Approach. Dubuque, IA: Brown \& Benchmark.

Perozynski, L \& Kramer, L 1999. Parental Belief About Managing Sibling Conflict. Journal of Developmenta! Psychology. vol 35, $2,489-499$.

Santrock, JW. 2001. Adolescence. New York: McGraw-Hill Companies

Santrock, JW. 1999. Life-Span Development (7 $7^{\text {th }}$ ed). New York: McGraw-Hill.

Shaffer, D.R. 1994. Social \& Personality Development (3rd ed). California: Brooks/Cole Publishing Company. 